\title{
Penerapan Metode Edutainment Berbasis Animasi untuk Meningkatkan Hasil Belajar IPA pada Siswa Kelas VIII di SMP Negeri 9 Palu
}

\author{
Grace Anasstasia Tunde, Fihrin, dan Amiruddin Kade \\ Grace0893@yahoo.com \\ Program Studi Pendidikan Fisika FKIP Universitas Tadulako \\ Jl. Soekarno Hatta Km. 9 Kampus Bumi Tadulako Tondo Palu - Sulawesi Tengah
}

\begin{abstract}
Abstrak - Penelitian eksperimen ini bertujuan untuk mengetahui peningkatan hasil belajar IPA melalui penerapan metode Edutainment berbasis Animasi pada siswa SMP Negeri 9 Palu. Jenis penelitian ini menggunakan metode pre-experimental design yang diterapkan pada satu kelas eksperimen dengan jumlah populasi sebanyak 225 orang dan jumlah sampel sebanyak 26 orang. Desain penelitiannya berupa "One group pretest-posttest design". Sampel dipilih secara purposive sampling yang merupakan teknik penentuan sampel dengan pertimbangan dari guru mata pelajaran fisika. Kelas yang dipilih adalah kelas yang sifatnya homogen. Sampel dalam penelitian ini yaitu kelas VIII A sebagai kelas eksperimen. Nilai rerata tes awal yang dioeroleh 11,19 dan tes akhir 16,84 dengan skor maksimum 23. Dari uji hipotesis postest yang menggunakan uji-t (uji dua sampel berhubungan) diperoleh thitung sebesar 4,38 pada taraf signifikasi $a=0,05$ dan tabel $=1,71$. Berdasarkan uji N-gain diperoleh peningkatan hasil belajar pada kelas eksperimen yaitu 42,37\%. Sehingga dapat disimpulkan bahwa terdapat Peningkatan Hasil Belajar IPA pada Siswa Kelas VIII A di SMP Negeri 9 Palu.
\end{abstract}

Kata Kunci : Metode Edutainment, Animasi, Hasil Belajar Fisika

\section{PENDAHULUAN}

Pendidikan merupakan pendewasaan peserta didik agar dapat mengembangkan bakat, potensi, dan keterampilan yang dimilikinya[1].

Sebuah realita dapat terlihat bahwa interaksi pembelajaran fisika masih sangat rendah, baik interaksi antar siswa maupun interaksi siswa dengan guru. Kurangnya juga motivasi siswa dalam belajar fisika sehingga minat belajar fisika siswa masih sangat kurang menyebabkan prestasi siswa untuk belajar fisika masih banyak belum memenuhi standar ketuntasan.

Belum maksimalnya hasil belajar IPA Fisika siswa disebabkan karena masih Kurangnya minat siswa dalam mempelajari fisika. Hal ini disebabkan karena siswa belum mengerti dan memahami dasar-dasar dari fisika dalam perhitungan pengubahan satuan, sehingga siswa merasa malas dan jenuh dalam mempelajari fisika. Salah satu upaya untuk mengatasi kejenuhan dan kemudahan dalam proses pembelajaran dan memberi kesempatan pada siswa untuk lebih aktif adalah dengan edutainment.

Konsep edutainment ini mampu mensinergikan antara pendidikan dan edutainment yaitu sesuatu yang menyenangkan dan menghibur patut untuk dijalankan, Suasana belajar harus diciptakan sedemikian rupa agar siswa tidak merasa terbebani dengan beragam materi, perasaan senang dapat hadir seiring dengan tujuan pendidikan yang dapat di serap dengan baik dan mudah sehingga dapat menarik minat belajar siswa. Karena dengan suasana pembelajaran yang menyenangkan maka secara tidak langsung dapat menarik minat belajar siswa sehingga dapat memaksimalkan hasil belajar siswa[2].

Pada dasarnya, edutainment berusaha untuk mengajarkan atau memfasilitasi interaksisosial kepada para peserta didik dengan memasukkan berbagai pelajaran dalam bentuk hiburan yang sudah akrab di telinga mereka, seperti acara televisi, permainan yang ada di komputer atau video games, film, musik, website, perangkat multimedia dan lain sebagainya. Di samping itu, edutainment juga bisa berupa pendidikan di alam bebas, yang mampu menghibur. Belajar yang menyenangkan, menurut konsep Edutainment bisa dilakukan dengan menyelipkan humor dan permainan (game) ke dalam proses pembelajaran, tetapi bisa juga dengan cara lain, misalnya dengan menggunakan metode bermain peran (role play), demonstrasi, dan multimedia[3].

Salah satu alternatif yang dapat mendukung proses pembelajaran adalah pemanfaatan media pembelajaran, pemakaian media pembelajaran dalam proses pembelajaran dapat membangkitkan keinginan dan minat 
yang baru, membangkitkan motivasi dan rangsangan kegiatan belajar, dan bahkan membawa pengaruh-pengaruh psikologi terhadap siswa[4].

Media animasi adalah hasil teknologi modern yang membuka kemungkinan-kemungkinan yang besar alat pendidikan. Hal ini bisa menjadikan terciptanya suasana yang kondusif. Siswa akan lebih memperhatikan materi yang disampaikan guru, sehingga terjalin interaksi yang menyenangkan antara siswa dan juga guru [5].

Dengan demikian, metode Edutainment berbasis Animasi dapat meningkatkan hasil belajar siswa. Hal ini disebabkan karena dalam proses pembelajaran siswa merasa senang, tidak tertekan dan tidak merasa bosan sehingga siswa memiliki minat, motivasi dan interaksi dalam proses pembelajaran [5].

Tujuan dalam penelitian ini adalah untuk mengetahui peningkatan hasil belajar IPA melalui penerapan metode edutainment berbasis animasi pada siswa kelas VIII di SMP Negeri 9 Palu.

\section{METODE PENELITIAN}

Jenis penelitian ini adalah penelitian eksperimen lemah (pre-experimental design). Adapun desain penelitian ini menggunakan "One group pretest-posttest design" yaitu penelitian yang dilaksanakan hanya dengan menggunakan satu kelas saja yang dijadikan sebagai kelas eksperimen. Bentuk desain penelitiannya disajikan pada Tabel 1 :

Tabel 1. Desain Penelitian "One group pretest-posttest design"

\begin{tabular}{cccc}
\hline Group & Tes Awal & Perlakuan & Tes Akhir \\
\hline $\mathrm{E}$ & $\mathrm{O}_{1}$ & $\mathrm{X}$ & $\mathrm{O}_{2}$ \\
\hline
\end{tabular}

Keterangan :

E : Kelas eksperimen

$\mathrm{X}$ : Metode pembelajaran Edutainment berbasis Animasi

$\mathrm{O}_{1} \quad$ : Tes awal (preetest)

$\mathrm{O}_{2} \quad$ : Tes akhir (postest)

Populasi dalam penelitian ini sebanyak 225 orang yaitu seluruh siswa kelas VIII SMP Negeri 9 Palu tahun ajaran 2015/2016 yang terdiri dari 9 kelas. Sampel dalam penelitian ini sebanyak 26 orang yang merupakan sebagian dari siswa kelas VIII SMP Negeri 9 Palu yaitu kelas VIII A sebagai kelas eksperimen. Penarikan sampel pada penelitian ini ditentukan dengan metode pengambilan smapel yang digunakan secara purposive sampling atau penentuan sampel dengan pertimbangan tertentu.
Instrumen yang digunakan dalam penelitian ini adalah RPP, LKS, dan tes untuk melihat hasil belajar siswa. Tes tersebut digunakan untuk mengetahui peningkatan hasil belajar siswa yang menjadi sampel penelitian dengan penerapan metode edutainment berbasis animasi. Tes dibuat dalam bentuk tes pilihan ganda yang berjumlah 47 soal. Sebelum diuji cobakan di sekolah, terlebih dahulu divaliditas ahli, yang divalidasi seperti pembuatan soal yang sama, jawaban yang terdapat kekeliruan, struktur kalimat yang perlu diperjelas, dan serta satuan-satuan yang digunakan, kemudian soal tersebut diuji cobakan pada siswa kelas IX SMP Negeri 9 Palu yang telah melewati materi getaran dan gelombang.

Data yang diperoleh dari penelitian ini selanjutnya diolah menggunakan uji statistik yaitu uji normalitas, uji homogenitas, dan uji hipotesis yaitu uji-t (uji dua sampel berhubungan).

\section{HASIL DAN PEMBAHASAN}

Tes awal dilakukan setelah selesainya ters uji coba pada kelas IX. Penggunaan tes awal diberikan untuk melihat peningkatan hasil belajar siswa dengan membandingkan hasil belajar sebelum diberi perlakuan dan setelah diberi perlakuan. Hasil penelitian dapat dilihat pada tabel 2 .

Tabel 2. Deskripsi skor tes hasil belajar fisika siswa untuk kelas eksperimen

\begin{tabular}{lcc}
\hline \multirow{2}{*}{ Uraian } & Tes awal (Pretest) & Tes akhir (Posttest) \\
\cline { 2 - 3 } & Eksperimen & Eksperimen \\
\hline Sampel $(\mathrm{n})$ & 26 & 26 \\
Skor maksimum & 17 & 23 \\
Skor minimum & 6 & 16 \\
Skor rata-rata & 11,34 & 16,96 \\
Standar deviasi & 2,66 & 2,43 \\
\hline
\end{tabular}

Sebelum dilakukan pengujian hipotesis terlebih dahulu dilakukan uji normalitas dan uji homogenitas data. Hasil uji normalitas dan uji homogenitas menunjukkan bahwa data ini sudah terdistribusi noormal dan homogen.

Setelah uji normalitas dan uji homogenitas, maka di lakukan uji-t (Uji duasampel berhubungan ). Berdasarkan skor tes akhir (posttest) pada kelas eksperimen diperoleh nilai thitung $=4,38$ dan tabel $=1,71$. Dari hasil analisa data tes akhir yang ada diperoleh bahwa $\mathrm{H}_{0}$ ditolak sedangkan $\mathrm{H}_{1}$ diterima atau dengan kata lain hasil belajar siswa setelah diberikan perlakuan dengan penerapan metode Edutainment berbasis Animasi pada postest 
lebih meningkat dari siswa sebelum diberikan perlakuan pada pretest.

Peningkatan hasil belajar siswa dapat dilihat pada nilai rerata $\mathrm{N}$-gain yang didapatkan pada kelas eksperimen yaitu $42,37 \%$, termasuk dalam kategori sedang. Meningkatnya hasil belajar siswa disebabkan karna adanya penyampaian materi kepada siswa yang mudah dipahami, menggunakan contoh dalam kehidupan sehari-hari dan memperlihatkan animasi dari materi yang disampaikan sehingga siswa tidak hanya mengkhayal dan juga Proses pembelajaran yang dilakukan di dalam kelas sangat menyenangkan sehingga tidak menimbulkan kejenuhan, ketegangan dan kebosanan pada siswa saat proses belajar. Serta pemberian game pembelajaran aktif, hal ini dilakukan agar siswa tidak merasa bosan dan jenuh dan dapat merilekskan otak dan secara tidak langsung dapat melihat sampai dimana pemahaman siswa terhadap materi yang sudah diajarkan.

Peningkatan hasil belajar siswa ini terjadi juga karena guru dan siswa terlibat aktif bersama-sama dalam pembelajaran. Berdasrkan penelitian yang telah dilakukan, bahwa hasil rata-rata belajar dapat ditingkatkan dengan pembelajaran metode Edutainment dengan media animasi ataupun simulasi [5].

Hasil yang diperoleh sesuai dengan teoritis seperti pada penelitian sebelumnya Indriati [4] menyatakan bahwa hasil rata-rata belajar dapat ditingkatkan dengan pembelajaran metode Edutainment dengan media animasi ataupun simulasi. Arief Widyatmoko [6] menyatakan bahwa (1) Pembelajaran IPA Fisika dengan pendekatan physics-edutainment berbantuan CD pembelajaran interaktif dapat meningkatkan hasil belajar siswa. (2) Minat belajar siswa terhadap pelajaran IPA Fisika dengan pendekatan physics-edutainment berbantuan $C D$ pembelajaran interaktif mengalami peningkatan dari kategori berminat menjadi kategori sangat berminat.

\section{KESIMPULAN}

Berdasarakan penelitian dan analisis data hasil penelitian, maka dapat disimpulkan bahwa penerapan metode Edutainment berbasis animasi dapat meningkatkan hasil belajar IPA (fisika) pada kelas VIII A SMP Negeri 9 palu. Rata-rata hasil belajar siswa pada tes awal sebesar 11,34 dan tes akhir sebesar 16,96 untuk kelas eksperimen. Meningkatnya hasil belajar siswa didukung adanya penyampaian materi kepada siswa yang mudah dipahami, menggunakan contoh dalam kehidupan sehari-hari dan memperlihatkan animasi dari materi yang disampaikan sehingga siswa tidak hanya menghayal, dan juga menciptakan suasana kelas yang menyenangkan serta melakukan game pembelajaran aktif sehingga membuat siswa tidak merasa tertekan, bosan dan jenuh.

\section{DAFTAR PUSTAKA}

[1] Daryanto. (2009). Panduan Proses Pembelajaran Kreatif dan Inovatif. Jakarta: Pubisher.

[2] Haid, S.M. (2011). Metode Edutainmment.Yogyakarta : DIVA Press.

[3] Hamruni. (2008). Konsep Edutainment Dalam Pendidikan Islam. Yogyakarta : Bidang Akademik UIN Sunan Kalijaga.

[4] D. Indriati S.C.P. (2012). Meningkatkan Hasil Belajar IPA Konsep Cahaya melalui Pembelajaran scienceedutainment Berbantuan Media Animasi. Jurnal Pendidikan IPA Indonesia 1(2):192-197 Tersedia di http://journal.unnes.ac.id/index.php/jpii (diakses 151-2013).

[5] Abdan. Meningkatkan Hasil Belajar IPA Konsep Cahaya Melalui Pembelajaran Science-Edutainment Berbantuan Media Animasi. Jurnal Kreatif Online, Vol. 4 No. 4. 2016.

[6] Widiyatmoko, A. (2010). Penerapan Pendekatan Science Edutainment Berbantuan CD Pembelajaran Interaktif untuk Meningkatkan Hasil Belajar Minat Siswa. Prosiding Seminar Nasional Pascasarjana Unnes dengan tema Peningkatan Profesionalitas Guru Melalui Publikasi Karya Ilmiah. Semarang, 24 Juli 2010. 